\title{
Analyze the Effect of First Media Service Quality Towards Consumer Satisfaction Using the ServQual Method
}

\author{
Maulana Rezi ${ }^{1, a^{*}}$, Gilang Chandra ${ }^{1, b}$, Satiadji Budiman ${ }^{1, c}$, Gandy Putra ${ }^{1, d}$, Arighi Rizki ${ }^{1, e}$ \\ ${ }^{1}$ Department of Information Systems, Faculty of Engineering and Computer Science, Indonesian Computer University, Bandung, 40132, Indonesia \\ a rezimaulana@mahasiswa.unikom.ac.id; b gilangchandraw@mahasiswa.unikom.ac.id; c budiman.satiadj@mahasiswa.unikom.ac.id; \\ d gandy.pc12@mahasiswa.unikom.ac.id; e arighi.rizki@mahasiswa.unikom.ac.id \\ ${ }^{*}$ Corresponding Author: rezimaulana10@gmail.com \\ Whatsapp Number [081222250467]
}

How to Cite : Rezi, M., Chandra, G., Budiman, S., Putra, G., Rizki, A. (2019). Analyze the Effect of First Media Service Quality Towards Consumer Satisfaction Using the ServQual Method. International Journal for Educational and Vocational Studies, 1 (3), 189-192.

\section{ARTICLE HISTORY}

Received:3 May 2019

Revised: 23 June2019

Accepted: 29 July 2019

\section{KEYWORDS}

Media Service Quality; Consumer Satisfaction; ServQual Method

\section{ABSTRACT}

First media is one of the companies in the field of recording technology that provides internet network services. To find out the value of the influence of first-class operators on consumer satisfaction in this study used the associative method. Descriptive method to determine the level of buyer satisfaction with the operator. This study used a questionnaire distributed to 100 consumers. The results showed that consumers who were very satisfied with the quality of service were as many as 39 people. Satisfied consumers are as many as 13 people, and consumers who feel dissatisfied are as many as 48 people. From the results of easy linear regression the miles are considered that the regression equation is $Y=-0.018+0.051 X$, which means the constant $(\beta 0)$ is -0.018 shows that when the service quality variable does not change, the average customer satisfaction $(Y)$ is -0.018 . Service quality regression coefficient of 0.051 . This shows that every one constant increase in service quality variables will increase customer satisfaction $(\mathrm{Y})$ by 0.051 . Positive regression coefficient, this shows the higher the first-class operator, the higher the customer satisfaction $(Y)$. From the calculation of $R 2$ termination coefficient, it is known that service quality has an influence of $50.5 \%$ on customer satisfaction.

This is an open access article under the CC-BY-SA license.

\section{INTRODUCTION}

With the development of information technology currently considered successful in because there is a balance between existing resources and the achievement of the objectives of the activity. This can be shown in several previous studies. Information systems began to be developed and implemented in secondary schools in their academics (Masturoh, Wijayanti, \& Prasetyo, 2019). The company is even willing to make an information system to fulfill the satisfaction of their customers (Saputri, Oktavia, Ramdhani, \& Suherman, 2019). In fact, mobile application can begin to affect entrepreneurial success (Hasan, Kahfi, Purnama, \& Syah, 2019). Internet network is one of the important components of information technology which is the foundation in achieving this development. The internet plays a role in connecting a device with other devices. Without the internet, this is impossible. According to (Iskandar \& Hidayat, 2015) internet network is an important requirement in an educational institution that will be used by teaching staff, students or even the general public who have needs in an institution. First Media is a company that runs in the field of information technology. As one of the companies running in the field of information technology, First Media provides Internet network services.
Consumers can use the internet network that has been provided by First Media after making a purchase transaction for the internet service. But consumers do not only want quality products or services, some things can be considered to be able to see whether consumers are satisfied with the internet services they normally use.

According to (Apriyani \& Sunarti, 2017) Service quality is an assessment to reflect a consumer's perception of the five physical dimensions and service performance. There are five dimensions that can be used to measure service quality, namely: (1) tangibles, (2) reliability, (3) responsiveness, (4) assurance, (5) empathy.

Quality is a matter that is intended to measure the level of customer satisfaction with high and includes the factors that are characteristic of a product and service (Stefano, Casarotto Filho, Barichello, \& Sohn, 2015). Satisfaction becomes a mediating factor between the level of quality of consumer perceptions and customer loyalty, if the level of service quality is satisfactory and consumers feel satisfied, then the level of satisfaction will affect consumer loyalty (Lei \& Jolibert, 2012). Quality becomes a basic factor in consumer decisions about a product or service (Rachman, 2019). 
According to (Apriyani \& Sunarti, 2017) Satisfaction or dissatisfaction is a response of a customer to an evaluation of incompatibility that can be felt with previous expectations. There is also an indicator: (1) Customers are satisfied with internet services. internet service is able to answer the expectations of a customer. (2) Customers are satisfied when we access the internet smoothly. the internet used by customers is free. (3) Internet services that meet customer expectations. Internet services that match what customers expect.

SERVQUAL method is a method that is widely used as a measure of service quality levels in the marketing field by finding a gap between the expectations and perceptions of service users (Kesuma, 2014).

ServQual was introduced and developed by Parasurman, Zaithaml \& Berry (1985), initially this method was created to evaluate service quality. This concept is based on five gaps, the last 5 gap includes differences between consumer expectations on service quality and consumer views on service quality (Pradela, 2015).

The final form of this model includes quantitative measurement of service quality which is divided into five dimensions: (1) tangibles, (2) reliability, (3) responsiveness, (4) assurance, (5) empathy. The ServQual method is used to analyze customer satisfaction with services in a complex way, and identify all problems that arise in the service process Wolniak \& Skotnicka-Zasadzien, 2012).

\section{METHOD}

The research objective is something that explains the impact in terms of service quality to customer satisfaction so that the research objectives can be assumed to be descriptive. The research method is associative based on the level of explanation, in other words looking at the relationship between two variables namely customer satisfaction and service quality obtained from the survey results. According to (Sutanto, 2011). to achieve the goal, there will be several steps that need to be carried out for this study, namely as follows:

making a questionnaire,

data collection and data collection,

processing and analyzing data,

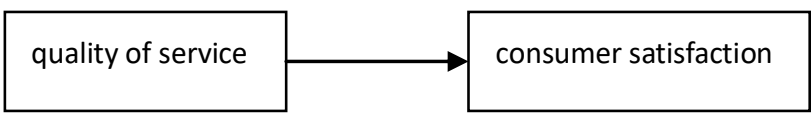

Fig 1. Service Quality for Consumer Satisfaction

Data collected is quantitative, because primary data sources are obtained from questionnaires through the distribution of posts using the internet and secondary data sources derived from library studies.

Questionnaire respondents were consumers who numbered 100 people. Questionnaire questions are arranged based on observed objects, so that each indicator is a question object. Each indicator represents one of the two dimensions of the

quality variable. Quality variables are divided into two dimensions, namely dimensions of perception and expectations.

The measurement method used is a method adapted from ServQual (Parasuraman \& Zeithaml, 2011). To explain the questionnaire used below is a description of quality variables divided into two dimensions and each dimension has five indicators.

In the questionnaire made for the survey each indicator has one question that includes one object. Assessment of the dimensions of perspective: (5) Strongly Agree, (4) Agree, (3) Indecisive, (2) Disagree, (1) Strongly Disagree. Assessment of the dimensions of expectations (5) Very Ideal, (4) Ideal, (3) Fairly Ideal, (2) Ideal Less, (1) Very Not Ideal.

Table 1. Questionnaire Item

\begin{tabular}{|l|c|l|}
\hline Indicator & Number & Questionnaire \\
\hline XP1 & 1 & $\begin{array}{l}\text { The customer service building } \\
\text { has a strategic location. }\end{array}$ \\
\hline XP2 & 2 & $\begin{array}{l}\text { Employees give individual } \\
\text { attention to consumers. }\end{array}$ \\
\hline XP3 & 3 & $\begin{array}{l}\text { Services provided are in } \\
\text { accordance with the promise. }\end{array}$ \\
\hline XP5 & 5 & $\begin{array}{l}\text { The response to customer } \\
\text { complaints is responded well. }\end{array}$ \\
\hline XE1 & 6 & $\begin{array}{l}\text { The company fosters } \\
\text { consumer trust in services. }\end{array}$ \\
\hline XE2 & 7 & Condition of service building. \\
\hline XE3 & 8 & $\begin{array}{l}\text { Conformity between service } \\
\text { and promises given. }\end{array}$ \\
\hline XE4 & 9 & $\begin{array}{l}\text { Response to customer } \\
\text { complaints. }\end{array}$ \\
\hline XE5 & 10 & Trust in the company. \\
\hline
\end{tabular}


Based on the table above is a table $\mathrm{Y}$ of customer satisfaction with first media services with the whole of the table above.

\section{RESULTS AND DISCUSSION}

In this section the researcher describes the results of the research along with the discussion. The distributed questionnaire consists of 10 questions consisting of 5 questions for service quality received (xp) and expected service quality (xe). After experiencing an instrument test consisting of what has been done by testing the validity and reliability test, the results will be obtained as follows:

Table 4. Validity Test

\begin{tabular}{llc}
\hline \multirow{2}{*}{ INDICATOR } & LABEL & $\mathrm{XP}$ \\
\cline { 3 - 3 } & & $\mathrm{R}$ \\
\hline TANGIBLE & $\mathrm{XP1}$ & 0.495223 \\
\hline EMPATHY & $\mathrm{XP2}$ & 0.426691 \\
\hline RELIABILITY & $\mathrm{XP3}$ & 0.358754 \\
\hline RESPONSIVENESS & $\mathrm{XP} 4$ & 0.487634 \\
\hline ASSURANCE & $\mathrm{XP5}$ & 0.478568 \\
\hline
\end{tabular}

\begin{tabular}{lll}
\hline \multirow{2}{*}{ INDICATOR } & LABEL & $\mathrm{XE}$ \\
\cline { 3 - 3 } & & $\mathrm{R}$ \\
\hline TANGIBLE & $\mathrm{XE1}$ & 0.452611 \\
\hline EMPATHY & XE2 & 0.403657 \\
\hline RELIABILITY & XE3 & 0.484534 \\
\hline RESPONSIVENESS & XE4 & 0.462278 \\
\hline ASSURANCE & XE5 & 0.421451 \\
\hline
\end{tabular}

The table above is a value of the correlation $\mathrm{r}$ (pearson correlation) for the whole question item is more than 0.30 , so it is concluded that the whole question is valid. Whereas for reliability values are described in the following table:

Table 5. Reliability Test

\begin{tabular}{|c|c|}
\hline Cronbach's Alphaa & $\mathrm{N}$ of Items \\
\hline 0.014 & 5 \\
\hline-0.013 & 5 \\
\hline
\end{tabular}

Based on the table above, it is known that each variable gets an alpha (a) value for $\mathrm{Xp}$ equal to 0.014 and for $\mathrm{Xe}$ is equal to -0.013. It was concluded that the whole question was not reliable or inconsistent so that for further research the items could not be used anymore.

Descriptive description of customer satisfaction with service quality as follows:
Table 6. Overview of Individual Satisfaction with

\begin{tabular}{lccc}
\multicolumn{4}{c}{ Service Factors } \\
\hline $\begin{array}{c}\text { Service } \\
\text { Indicator }\end{array}$ & $\begin{array}{c}\text { Very } \\
\text { Satisfied }\end{array}$ & Satisfied & $\begin{array}{c}\text { Not } \\
\text { Satisfied }\end{array}$ \\
\hline Tangible & 31 & 32 & 37 \\
\hline Emphaty & 38 & 31 & 31 \\
\hline Reliability & 33 & 36 & 31 \\
\hline Responsiveness & 32 & 23 & 45 \\
\hline Assurance & 28 & 34 & 38 \\
\hline
\end{tabular}

Based on the table above it is known that consumers are very satisfied with the empathy and reliability factors and are not satisfied with the responsiveness factor

Table 7. Overview of Personal Satisfaction with the Overall Service

\begin{tabular}{lc}
\hline Very Satisfied & 39 \\
\hline Satisfied & 13 \\
\hline Not Satisfied & 48 \\
\hline
\end{tabular}

Based on the table above it can be concluded that individual satisfaction in overall service factors, namely 39 people said they were very satisfied, 13 said they were satisfied and 48 people said they were not satisfied. The results of the associative analysis after going through the calculation procedure using SPSS v.20 are:

\begin{tabular}{|c|c|c|c|c|c|c|}
\hline \multicolumn{7}{|c|}{ Coefficients $^{a}$} \\
\hline & \multirow{2}{*}{ Model } & \multicolumn{2}{|c|}{$\begin{array}{l}\text { Unstandardized } \\
\text { Coefficients }\end{array}$} & \multirow{2}{*}{\begin{tabular}{|c}
$\begin{array}{c}\text { Standardized } \\
\text { Coefficients }\end{array}$ \\
Beta
\end{tabular}} & \multirow{2}{*}{$\mathrm{t}$} & \multirow{2}{*}{ Sig. } \\
\hline & & $\mathrm{B}$ & Std. & & & \\
\hline \multirow{2}{*}{1} & (Constant) & -0.02 & 0.101 & & -0.178 & 0.859 \\
\hline & $x$ & 0.051 & 0.005 & 0.71 & 9.994 & 0 \\
\hline
\end{tabular}

Fig 2. Results of Simple Linear Regression Analysis

Based on the picture above, it can be seen that the regression equation formed is $\mathrm{Y}=-0.018+0.051 \mathrm{X}$ which means that the constant (B0) of -0.018 indicates that when the variable Quality of service does not change so it can be seen from the average Customer Satisfaction (Y) is $-0,018$. With the service quality regression coefficient of 0.051 . This shows that every 1 constant increase in service quality variable will increase Consumer Satisfaction (Y) by 0,051 . Regression coefficient is positive. This shows that the better the quality of service, the better the Customer Satisfaction (Y).

To find out the magnitude of the effect of service quality on customer satisfaction, the calculation of the coefficient is terminated as follows:

\begin{tabular}{|llllllllll}
1 & $\mid .710^{\mathrm{a}}$ & 0.505 & 0.5 & 0.505 & 99.876 & 1 & 98 & 0 \\
\hline
\end{tabular}

Fig 3. Coefficient of Determination 
Based on the picture above it is known that R2 ( $R$ square) value. is equal to 0.50 so it is concluded that the quality of service has an impact of $50.5 \%$ on customer satisfaction.

\section{CONCLUSION}

Something in terms of service quality consisting of tangible, empathetic, reliability, responsiveness and assurance factors has had a significant influence on customer satisfaction. It is evident that individually consumers are satisfied with the services provided. The level of consumer satisfaction was $52 \%$ (very satisfied at $39 \%$ and satisfied by $13 \%)$.

Service quality has a positive influence on customer satisfaction with the terms the better the service, the better the customer satisfaction. While the magnitude of the impact obtained by service quality on customer satisfaction is $50.5 \%$. Suggestions that can be learned are improving service to consumers for indicators of responsiveness.

\section{REFERENCES}

Apriyani, D. A., \& Sunarti. (2017). The Effect Of Service Quality On Customer Satisfaction (Survey on Consumers of The Little A Coffee Shop Sidoarjo). Journal of Business Administration (JAB) Vol. 51 (2), 1-7. Retrieved from www.bisnissurabaya.com

Dhaniawaty, R. P., \& Susilawati, E. (2018). Development Of Information Systems Reporting Work Programs And Data Management Management Of Student Collection In Information System Study Programs. Journal of Information Management (JAMIKA) UNIKOM, 8 (2), 1-11.

Hasan, M., Kahfi, A. H., Purnama, D., \& Syah, A. (2019). Analysis of the Effect of Mobile Applications in Supporting Entrepreneurial Success in Bekasi City. Informatics Journal Bsi, 6 (1), 47-52.

Iskandar, I., \& Hidayat, A. (2015). Campus Internet Network Quality of Service (QoS) Analysis (Case Study: UIN Suska Riau). CoreIT Journal, 1 (2), 2460-2738.

Kesuma, D. P. (2014). Xyz College Web Service Quality Measurement Analysis Using Servqual. 2014 National Seminar on Informatics, 178-183.

Lei, P., \& Jolibert, A. (2012). A three-model comparison of the relationship between quality, satisfaction and loyalty: an empirical study of the Chinese healthcare system. BMC Health Serv Res, 12(4), 36-59.

Masturoh, S., Wijayanti, D., \& Prasetyo, A. (2019). Implementation of the Waterfall Model in Web-Based Academic Information Systems at the Middle School of Agriculture in Karawang. Journal Of Informatics Bsi, 6 (1), 137.

https://doi.org/10.33480/techno.v15i2.923

Parasuraman, A., \& Zeithaml, V. (2011). A Conceptual Model of Service Quality and Its Implication for Future Reaserch. Service Quality.
Pradela, A. (2015). Quality of Graduates' Preparation for Labour Market - A ServQual Analysis. Procedia Social and Behavioral Sciences, 174, 1671-1677. https://doi.org/10.1016/j.sbspro.2015.01.820

Rachman, R. (2019). Application of the AHP Method to Determine the Quality of Apparel in the Garment Industry. Informatics Journal Bsi, 6 (1), 1-8.

Saputri, Z. R., Oktavia, A. N., Ramdhani, L. S., \& Suherman, A. (2019). Design a web-based food ordering information system at Surabiku Cafe. Journal of Technology and Information (JATI) UNIKOM, 9 (1), 66-77.

Sutanto, A. (2011). Motor Sm Di Kota Padang Dengan Metode. 10(2), 154-159.

Stefano, N. M., Casarotto Filho, N., Barichello, R., \& Sohn, A. P. (2015). A fuzzy SERVQUAL based method for evaluated of service quality in the hotel industry. Procedia CIRP, 30, 433-438. https://doi.org/10.1016/j.procir.2015.02.140

Wolniak, R., \& Skotnicka-Zasadzien, B. (2012). The concept study of Servqual method's gap. Quality and Quantity, 46, 1239-1247. 